Urszula Paszkiewicz

\title{
NIEZNANE DRUKI POZNAÑSKIE OPISANE PRZEZ ZYGMUNTA MOCARSKIEGO
}

Wśród rękopisów Zygmunta Mocarskiego natrafizam na interesujący fragment jego odkryć bibliograficznych dokonarych $w$ Piotrogrodzie około 1916 roku. Artykuł "Nieznane ksiązki polskie /Notatka bibliograficzna/"1, pisany najprawdopodobniej do rosyjskiego czasopisma bibliologicznego ${ }^{2}$, tylko w części został ogłoszony drukiem w odroUzonej Polsce ${ }^{3}$. N1o opublikowany dotyohozas fragment rekoplsu wydaje się tym cenniejszy, iż wzbogaca stan badań nad dziejami drukarstwa poznańskiego początków XVIII stulecia. Dziçki odkryciu Mocarskiego, możemy bowiem uzupęnić wiedzę na temat dziazalności Józefa Wolnskiego, poznańskiego introligatora, księgarza i nakładcy. Jan Sójka ustalił ${ }^{4}$, opjerając się no dostępnych jemu żródłach, że wolnski około 1717 roku został dzierżawcą Drukarni Akademickiej w Poznaniu i pozostawał nim na pewno do 31 pazidzierrika 1720 roku. Wobec braku źródeł, nie udało sį̧ autorowi stwierdzić, czy pó́niej Wolnski był nadal dzierżawca Drukarni Akademickiej. Za czasów Wolnskiego Drukarnia odbiła siedemnaście druków, przy czym yszystikie były opatrzone tylko nazwa oficyny ${ }^{5}$. Omawiajac także dzieje Drukarni Akademickiej Sójka przyją, iż dzierżawcy oficyny "sygnowali. tylko te pozycje, które ukazywały się ich nakiadem i to zwykle obok właściwej firmy"6. W tomie wielkopolskim "Drukarzy dawnej Polski od XV do XVIII wieku" czytamy ponadto, iz "działalność nakładczą rozpoczął Wolnski już ok. 1718 r. i zwiazzał ja całkowicie z poznańską Orukarnią Akademicką" "W 1720 roku wydał swoin nakładem dwa druki: "Tractatus asceticus ..." oraz "Preces Gertrudianae...". Kolejnym drukiem, wydanym przez Wolnskiego w Drukarni. Akademickiej, był - według sojki - "Tron ojczysty albo pałac wieczności..." Augustyna Koludzkiego z 1727 roku ${ }^{8}$. Dwa druki z 1722 roku opisane przez Mocarskiego z autopsjị ${ }^{9}$. pozostaja zatem daloj nie znane ${ }^{10}$. Przytaczam fragment wsponnianøgo rękopisu, powstałego $w$ trakcie posztkiwań Mocarskiego w Bibliotece Cosarskiaj Akademit Nauk w Piotrogrodzie. "Karta tytułowa zawiera następujace słowa: 》D $z \pm$ a $r$ 
$\mathrm{d} y \mathrm{n}^{11} / / \mathrm{du} \mathrm{c} \mathrm{h}$ ow $\mathrm{n} y, / /$ Rozlicznym IKwiaćiem Niebieslciegro Odoru násádzony: // To iest // $\mathrm{N}$ a $\mathrm{b}$ o $z$ e n $\mathrm{s} t \mathrm{w}$ a $\mathrm{in} i / /$ Do

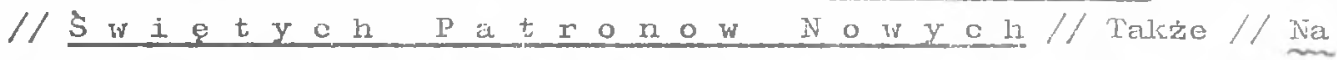
wszystkie całego Roln Swieta, wdzigczneni Nffelstani $/ /$ orzdobiony. $/ / \mathrm{y} / / \mathrm{Na}$ Ręce Jaśnie Wielnoźnych Ich MCiow P.P. // D a b 5 k i c l / I// złożony, // A // Za pozwoloniem Zwienzchnośi. Duchowney // Do Druku // podany //W P o z n a n i u, / w Drukarni Niadomickiey, Isosztem Jozefa Wolnskiego, R.P. 1722". Na odwrotnej stromie karty tytulowej miedzioryt przedstawia połączone herby Dąmbskich i Krąkowskich /Godziemba i Trąhy/. Rozmiar $19^{1 / 2}$ x 16 cret. $\left.1 \mathrm{n}\right\} \mathrm{b}$. $4+\mathrm{str} \cdot 278+\mathrm{knlb}$. Dalejw tejze oprawie idzie inny drulk "Kosztem

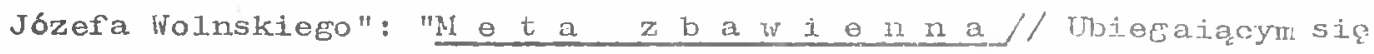
do Szczęśliwey wieczności //w y mi e r z o na// Przez// codzienne nabozenstwa // gorące affelty // Zarliwe Aikty do Boga w Troycy S.Iedynego, // talkze do Przenays: Maryi Panny y rożnycli l’atronow y

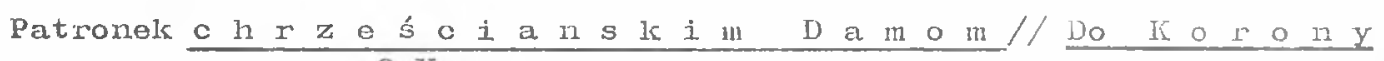

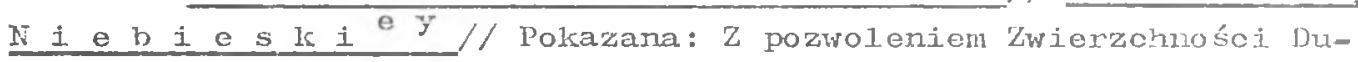
chowney // Do Druku // $\mathrm{P}$ o d a $n$ a $/ / \mathrm{w} P$ P z n a n u, // w Drukarnl Akademickiey, Kosztem Jozefa Wolnsikiego R.P. 1722". Na odwrotnej stronie karty tytułowej iniedzioryt przedstaria herij Szoldrskich /Lodzia/. Kart nlb.1 + str. 294 + linlb. regestru. Oba druki. oprawne razem moga być tez uwazane za jedną całość, bo na str. pi.erwszej "Mety zbawiennej". inna liczba: str. 279 wskazuje, ze druk ten łączy się niejalio z przedostatniq str. 278 "Dziardynu duchownego". Treść ksiąži / jak moźna przypuszczać z tytułów/ słkłada sį̨ z roznaitych nabozeŕstw, litanit, modiltw itd. Farty nleliczbowane "Dziardynu duchownego" zawierają tłoczony drukiem dwulcolororym Iralendarz roczny 12 .

Zygmunt Mocarsli zwrócił uwage na istotne cech bibliograficzne unikalnych druków Józefa Wolnskiego, dając jednoczesnie ryraz niezwykłej troski o ocalenie paniętek narodowych. Kilka lat póniej zEłosil nawet postulat opracowania bibliografii zaginionych dawnych drukón polskich lub Polslsi dotyczących ${ }^{13}$.

Dra druli poznańskie opisane przez Mocarskiego powinny zaciekawié nie tylko listorylców drukarstwa polslkiego. Na podkreślenie zasługuje równiez falit, iz wspomniany egzenplarz pochodzi z lcsięgozbioru Konstancji z Radziviłłów Sapiezyny. Dowodzi tego ekslibris umieszczony na wewnetrznej stronie oprawy ${ }^{4}$, wylkonany w 1741 roku przez wybitnego rytownika gdariskiego Jana Fryderyka Myliusa. Wartości estetyczne elcslibrisu przypomiala niedarmo Hanna Wolslca omawia jąc ksiegozbióx Konstanoji Sapiezyny w świetle inwentarza z 1757 roku 
W dotychczasowej literaturze ksieggoznawczej podnoszone byzy nie tylko walory estetyczno znaku wasncściowego, zwracano przecle wszystlim uwage na f'alst, ze jest to pienrszy znany polslii elsslibris kobiecy i najwcześniejszy elsslibris z napisem w jezylsu polskim ${ }^{16}$. Zgodnie z relcopisem Mocarskiego, napis ten brzui: "Z biblioteli Ias: Osw: Xięznej I’uści Konstancyi z Radziwilłów Sapieżyry Tauclerzyney Wielkiey $W^{0} \cdot X^{a} \cdot L^{0} \cdot 1741^{17}$. Warto rómiez przypommieć, iz w 1916 roku Mocarski zglosił postulat opracowania historii biblioteki ksiąząt Radziwil1

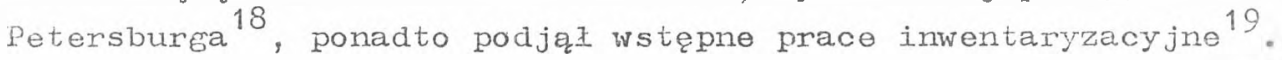
Przypuszczalnie u trakcie tych prac powstaly "Nieznane książi ¡olskie", a takze artykuł opublikowany dziesieć lat póśniej, w którym Mocarski opisał dwa inne druki pochodzące z księgozioru nieświeskiego, a znajdujące się w Hibliotece Cesarslriej Mkadenii $\operatorname{Nauk}^{20}$.

Skromy objętościovo fragnent rękopisu Mocarskiego dostarcza cennych informacji do dziejór ksiezkli polsisiej piemszej polowy IVIII wieku.

P r z y

1 Ręlopis liczący $i 1$ stron jest w posiadaniu syna autora, Szymona Mocarslsiego.

2 Na marginesach rękopisu znajduja się wskazórki autora: "luursiwom", "ra szpacii". O przeznaczeniu artylsułu do druku świadczą ponadto dwie strony nieliczbowane rękopisu, na których Mocarski. zamieśił opis osmiu ilustracji do telsstu, obiektów tych jednali bralruje.

3 Z.Mocarski, Modlitewnik księdza Tetmajera/Notatka bibliograficzno-genealogiczna/, Tygodnik Ilustrowany r.62: 1921, nx 19, s. 306 , ilustr.

4 Drukarze dawnej Polski od XV do XVIII wieku, t. 3, cz.1: Wielkopolska. Oprac.: Alodia Kawecka-Gryczowa, Krystyna Korotajowa, Jan S6jka, Wrocław 1977, s. XV, 305, 2 nłb., tab1. 27, err. Polslsa" Akademia Nauk. Instytut Badań Literackich. Ksiz̨żka iv dawnej 1sulturze polskiej. 10. Hasła: "Akademicka Drulkarnia Poznaí 1689-1780" oraz "Wolnslki Józef" w opracowaniu J.Sójlкi.

5 Ibiden, s. 267 . 
6

Ibidem, s. 21.

7 Ibidem, s. 268 .

8

Ibidem, s. 268-269.

9 Swiadczy o tym zachowanie ukladu graficznego karty tytułowef, oznaczenie koloru drulsu, a talkze szczegbły odnoszące się do charakterystylki opisyranogo egzemplarza.

10 Nie notują ich: "Bibliogratia polslca" K. Estreichera, katalog starych diuków Eibliotelki Narodowej w Warszavie, ani centralny latalog starych drukbow wielkopolskich znajdujący sio w Bibliotece Kómickiej PAN, ani tez centralny katalog starych arulckw w bibliotekach polskich, znajdujący się w Zakładzie Starych Druków Biblioteki Narodowej.

11 Przypis Z. Mocarskiego: "Druk rozstrzelony oznacza słowa tłoczone czerwong farbą", słowa podloreślone liniq prostą - drulciem rozstrzelonym, słowa podkreślone węzylkiem - kursywa..

12 z.Mocarski, Nieznano ksiązlci polslsie. s . 3-4.

13 Z.Mocarski, Zapiski Towarzystwa Naukowego w Toruniu, t.7: 1926, nr 4, s. 121. Recenzja dwóch bibliogrefii Karola Badeckiego; "Literatury mieszczańskiej w Polsce XVII wieku" i "Nieodszukanych pierwodruków literatury miesmczabskiej w Polsce XVII iv.".

14

Z.Mocarski, Nieznane lssiążki polskie, s. 2-3.

15 II. Wolska, Ksiegozbiór Konstancji Sapieźyny w świetle inwenta. rza z 1757 roku, w: Z badaí nad polskimi księgozbiorami historycznymi. Praca zbiorowa pod red. Barbary Bienkowskiej, z. 2, Warszawa 1976 , s. 133-154.

16 Ibidem, s. 147 .

17 Według opisu Wiktora Wittyga:"Z Biblioteki Jaśnie oświeconej Księznej Jejmości Konstancji z Raciziwiłłow Sapiezynej Kanolerzynej Wielkiej $\mathbb{V}^{\circ} \mathrm{Ks}^{\mathrm{a}} \mathrm{L}^{\circ} 1741 "$. W. Wittyg, Ex-librisy bibliotek polskioh XVII i XVIII w., t. 1, Warszawa 1903, s. $67 /$.

18 Z.Mocarski, W sprawie imwentaryzacji druków polskich, Myśl Narodowa R. 1: 1916, t. 2, nr 8/9, s. 291-292.

19 Inwentaryzacja biblioteki nieświeskiej Radziwiłłó miała być wykonana dla Koła Piotrogrodzkiego Warszawskiego Towarzystwa Opieki nad Zabytkami Przeszlości. W Ksiąznicy Miejskiej im. Kopernika w Toruniu / KM/ zachowaly się dwa listy kierownika Kola Aleksandra 
Borawskiego do Mocarskiego $w$ tej sprawie/Korespondencja Z.Mocarslkiego. Listy z 20 III 124 VIII 1916 r. KM rps 309 k.107-109/. 20 [Z.Mocarski] Zygm.Moc., Nieznane Estreicherowi druki wydane przez ks. Joachima Benedykta Chmielowskiego..., Silva Remun 1925 , t. $2, z .6$, s. 95 . 